\title{
Early Weaning and Part-year Confinement of Cattle on Arid Rangelands of the Southwest
}

\author{
C.H. HERBEL, J.D. WALLACE, M.D. FINKNER, AND C.C. YARBROUGH
}

\section{Abstract}

This study compared part-year confinement of cows with yearlong placement on rangeland and weaning calves in late May with regular weaning in mid-October. Weaning rates tended to be higher with part-year confinement than with yearlong placement on rangeland ( $86 \%$ vs. $72 \%$ ) and with early weaning in May than with regular weaning in October $(86 \%$ vs. $72 \%)$. There were significant year effects in weaning weights with the lowest weights in drought years. The production per cow exposed tended to be higher with part-year confinement than with yearlong placement on rangeland (134 kg vs. $110 \mathrm{~kg})$, and with regular weaning than with early weaning of calves $(156 \mathrm{~kg}$ vs. $88 \mathrm{~kg})$. Part-year confinement of cows and early weaning of calves are useful tools for the range manager in droughty years.

Production of livestock accounts for about $75 \%$ of the total agricultural income in the arid and semiarid regions of the Southwest. Much of this production is on rangelands. Because of frequent droughts, livestock production is particularly perplexing.

Every additional estrous cycle needed to get the beef cow rebred after parturition results in an economic loss. This loss is due to low weaning weights and eventually to cows left unbred at the end of the breeding season. Breeding performance is strongly affected by the cow's nutrition. Nutritional levels, before and after calving, influence pregnancy rate for next year's calf crop (Wiltbank et al. 1965). After parturition, the cow must provide milk for the growing calf as well as prepare for reproduction. This shift in feed requirements boosts dry matter and energy needs by about $40 \%$ and protein needs by about $120 \%$ (National Academy of Sciences 1976). Thomas and Durham (1964) suggested confinement of cows may relieve range plants during stress situations, such as drought, while satisfactory livestock production is maintained. Research in Texas indicated that conception rate was higher for cows in drylot than on rangeland (Marion et al. 1971). Confinement may improve livestock production when range forage is of low quality, or quantity, or both. In the Southwest, droughty periods in spring may be an ideal time to confine cows to drylot to rest range forage and maintain livestock production.

Suckling calves reduce reproductive activity of the dam. Several workers have suggested that suckling can be a major factor causing long postpartum intervals, particularly in young beef cows (Short et al. 1972, Laster et al. 1973, Bellows et al. 1974). Lusby et al. (1981) found early-weaned calves on concentrate feeds had about the same weight at seven months as calves remaining with their dams on native range in Oklahoma.

The primary purpose of this study was to compare performance of beef cows under 2 management systems: (1) conventional, yearlong on arid rangeland; and (2) part-year confinement in drylot, the remainder of the year on rangeland. A secondary objective was to compare cow performance with early weaning of calves and

\footnotetext{
Authors are supervisory range scientist, Jornada Experimental Range, ARS, USDA, Las Cruces, N. Mex. 88003; animal nutritionist and statistician (head), Agr. Exp. Sta., New Mexico State Univ., Las Cruces 88003: supervisory range technician, Jornada Experimental Range, ARS, USDA, Las Cruces, N. Mex. 88003.

This paper is a contribution of the Jornada Experimental Range, ARS, USDA, and the Agr. Exp. Sta., New Mexico State Univ., Las Cruces. 88003. Scientific Paper No. 978 of the latter.

Manuscript received December 6, 1982.
}

weaning at the usual time in both systems.

\section{Experimental Procedures}

This research was conducted on the Jornada Experimental Range $40 \mathrm{~km}$ north of Las Cruces, N. Mex. The climate is arid, 230 $\mathrm{mm}$ annual precipitation, $55 \%$ of which occurs in summer. The springs are often droughty and windy. The precipitation is highly variable spatially, and from time to time. The vegetation is dominated by black grama (Bouteloua eriopoda), tobosa (Hilaria mutica), mesa dropseed (Sporobolus flexuosus), and honey mesquite (Prosopis glandulosa).

Heifer calves born during the spring of 1973, 1974, and 1975 were placed in a lot about April 1 each year as yearlings and fed alfalfa hay free-choice and corn grain at the rate of $0.9 \mathrm{~kg} / \mathrm{head} /-$ day. Bulls were placed with these yearling heifers about May 1 , and were removed after a 65 -day breeding season. Without liberal feeding of alfalfa hay and some concentrates, the heifers would not have been heavy enough to satisfactorily breed when they were yearlings. Similar heifers on rangeland only, normally weigh 200 to $227 \mathrm{~kg}$, which is less than the weights found necessary for yearlings to breed satisfactorily. A total of 117 heifers of Hereford $(H)$, Santa Gertrudis (SG), H $\times$ SG, and SG $\times$ H breeds were alloted to the treatments by breeds. All the animals were returned to rangeland when the bulls were removed.

After breeding, the yearling heifers were divided into 4 treatments: (1) range-regular weaning (47 head), (2) range-early weaning (17 head), (3) part-year confinement-regular weaning (34 head), and (4) part-year confinement-early weaning ( 19 head). The group on range was treated as cows are customarily treated on arid rangelands of the Southwest, i.e., yearlong grazing with a minimum of supplemental feed. The amount of supplemental feed given to range cattlc is variable depending on forage conditions. In this study, each range cow received the following amounts of cottonseed meal pellets: $1977,39.0 \mathrm{~kg} ; 1978,45.2 \mathrm{~kg} ; 1979,24.1 \mathrm{~kg}$; $1980,60.3 \mathrm{~kg}$; and $1981,45.1 \mathrm{~kg}$. The group in part-year confinement was fed and handled the same as the yearlings during each spring. The breeding season was the same for each group and similar to that used for the yearlings. All calves were born on rangeland under similar conditions. Regular weaning was in midOctober when the calves were about 225 days of age. Early weaning was in late May when the calves were about 75 days of age. Additionally, we recorded sire, sex, and weaning weight of calves, and weight and pregnancy results from rectal palpation of cows in mid-October. We did not study calf performance following weaning from cows. All weights of heifer calves were adjusted by adding $5 \%$ of the weight to make them more comparable to steer calf weights (U.S. Department of Agriculture 1965). This study was terminated after calves were weaned in 1981. Because of normal culling procedures and death losses, 92 cows remained in the experiment until termination.

The basic experimental design was a split-plot in randomized complete blocks with 3 replications. All heifers born in 1973 were designated as Replication I and were treated as cohorts throughout the entire experiment. Similarly, heifers born in 1974 and 1975 
were designated as Replication II and Replication III, respectively. Therefore in the experimental design advantage was taken of the variability among the 3 cohort groups. Main plots consisted of the 2 environments (range vs. part-year confinement) and sub-plots were defined as the 2 weaning ages ( 225 vs. 75 days). Each year calving data from all cows within each sub-plot were averaged and this average was designated as the experimental unit for analysis.

In longitudinal research the effects of years and the effects of ages are confounded. These effects can be estimated, however, by grouping the data in 2 different ways for analyses. In order to estimate and compare year effects in conjunction with different environments and weaning ages, data for the last 5 years of each replication (1977-1981) were analyzed (ANOVA $\# 1$ ). This allowed age groups (months) to be somewhat confounded with replications as follows:

\begin{tabular}{|c|c|c|c|}
\hline Year & $\begin{array}{l}\text { Rep. } \\
\text { I }\end{array}$ & $\begin{array}{l}\text { Rep. } \\
\text { II }\end{array}$ & $\begin{array}{l}\text { Rep. } \\
\text { III }\end{array}$ \\
\hline 1977 & 54 & 42 & 30 \\
\hline 1978 & 66 & 54 & 42 \\
\hline 1979 & 78 & 66 & 54 \\
\hline 1980 & 90 & 78 & 66 \\
\hline 1981 & 102 & 90 & 78 \\
\hline
\end{tabular}

Considering the ages of cows in mid-October, these effects were estimated and compared by analyzing data for 5 age groups (ANOVA \#2). In this case the years were confounded with replications as follows:

\begin{tabular}{|c|c|c|c|}
\hline Age & $\begin{array}{l}\text { Rep. } \\
\text { I }\end{array}$ & $\begin{array}{l}\text { Rep. } \\
\text { II }\end{array}$ & $\begin{array}{l}\text { Rep. } \\
\text { III }\end{array}$ \\
\hline 30 & 1975 & 1976 & 1977 \\
\hline 42 & 1976 & 1977 & 1978 \\
\hline 54 & 1977 & 1978 & 1979 \\
\hline 66 & 1978 & 1979 & 1980 \\
\hline 78 & 1979 & 1980 & 1981 \\
\hline
\end{tabular}

Dependent variables analyzed included conception rate, weaning rate (the number of calves weaned per cow exposed), weaning weight ( 225 or 75 days) adjusted for sex, and production per cow exposed adjusted for sex. The separation of means, when appro- priate, were by the least significant difference (LSD) method. The LSD was applied only after a significant $F$-test $(p<.05)$ from the analyses of variance.

\section{Results}

There were essentially no differences among treatments in birth date of calves. The averages for year-cow age-treatment ranged from February 23-April 10.

Pregnancy rates of cows in mid-October were significantly higher $[p=.036$ (ANOVA \#1), .042 (ANOVA \#2)] for the part-year confinement group (92\%) than for the range group (74\%). Pregnancy rate in October tended to be higher for cows weaning calves in late May $(88 \%)$ as compared with cows weaning calves in midOctober ( $80 \%)$. The conception rate was only $44 \%$ of the range group in 1978 while the lowest in the part-year confinement group was $86 \%$ in 1977 (Fig. 1). Conception rates were much more

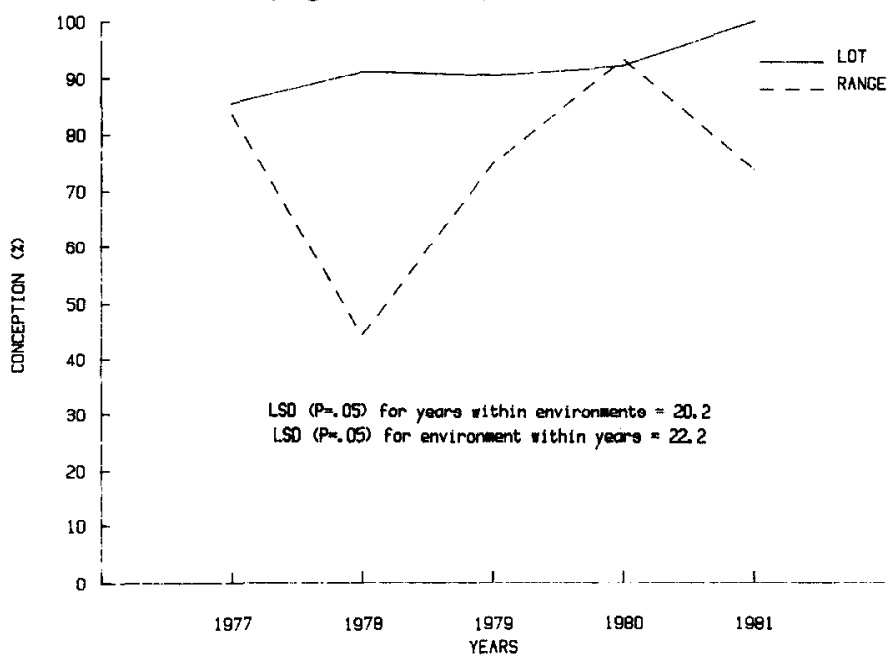

Fig. 1. Conception rates for the cows in part-year confinement and on rangeland yearlong, 1977-81.

Table 1. Average production per cow exposed under two environmental regimes and two weaning schedules.

\begin{tabular}{|c|c|c|c|c|c|}
\hline \multirow[b]{3}{*}{ Year } & \multirow{3}{*}{$\begin{array}{c}\text { Cow age in October } \\
\text { Month }\end{array}$} & \multicolumn{4}{|c|}{ Avg. production per cow exposed ${ }^{1}$} \\
\hline & & \multicolumn{2}{|c|}{ Regular weaning } & \multicolumn{2}{|c|}{ Early weaning } \\
\hline & & Range year long & Range/confinement & Range yearlong & Range/confinement \\
\hline & & & & - - & \\
\hline 1975 & 30 & 74 & 138 & 68 & 65 \\
\hline \multirow{2}{*}{1976} & 30 & 177 & 184 & 45 & 64 \\
\hline & 42 & 114 & 125 & 62 & 91 \\
\hline \multirow[t]{3}{*}{1977} & 30 & 91 & 117 & 94 & 74 \\
\hline & 42 & 107 & 200 & 71 & 73 \\
\hline & 54 & 151 & 206 & 68 & 107 \\
\hline \multirow[t]{3}{*}{1978} & 42 & 144 & 109 & 89 & 48 \\
\hline & 54 & 157 & 192 & 99 & 83 \\
\hline & 66 & 145 & 166 & 85 & 116 \\
\hline \multirow{3}{*}{1979} & 54 & 99 & 125 & 16 & 73 \\
\hline & 66 & 82 & 224 & 29 & 88 \\
\hline & 78 & 168 & 141 & 44 & 109 \\
\hline \multirow[t]{3}{*}{1980} & 66 & 92 & 147 & 101 & 100 \\
\hline & 78 & 181 & 144 & 90 & 113 \\
\hline & 90 & 134 & 180 & 78 & 118 \\
\hline \multirow{3}{*}{1981} & 78 & 259 & 211 & 83 & 122 \\
\hline & 90 & 160 & 252 & 110 & 94 \\
\hline & 102 & 160 & 137 & 111 & 134 \\
\hline Average $(1975-81)$ & & 142 & 170 & 78 & 97 \\
\hline Average $(1977-81)$ & & 139 & 166 & 75 & 93 \\
\hline
\end{tabular}

'These figures have been adjusted to reduce sex effects by adding $5 \%$ to all heifer calf weights. 
consistent for the cows in part-year confinement. Weaning rate tended to be lower in the range group [72\%, ANOVA \#1 and \#2] than in the part-year confinement group [86\% (\#1), 85\% (\#2)] $[p=.132(\# 1), .115(\# 2)]$. It also was lower in the cows with calves weaned at the regular time $[72 \%(\# 1), 71 \%(\# 2)]$ compared with cows with calves weaned early $[86 \%(\# 1), 87 \%(\# 2)](p=.051(\# 1)$, $.032(\# 2)]$. Weaning rate was significantly greater in $1978(82 \%)$, $1980(83 \%)$, and $1981(90 \%)$ than in $1979(62 \%)$.

Overall, there were no significant differences in adjusted weaning weights between calves from cows in part-year confinement or when the cows were on the range yearlong. The combined weaning weights over all treatments were significantly lower in 1978 than in 1979 and $1981(p=.001)$. Of the calves weaned in mid-October from cows in part-year confinement, weights were significantly higher in 1977, 1979, and 1981 than in 1980 (Fig. 2). The average daily gain

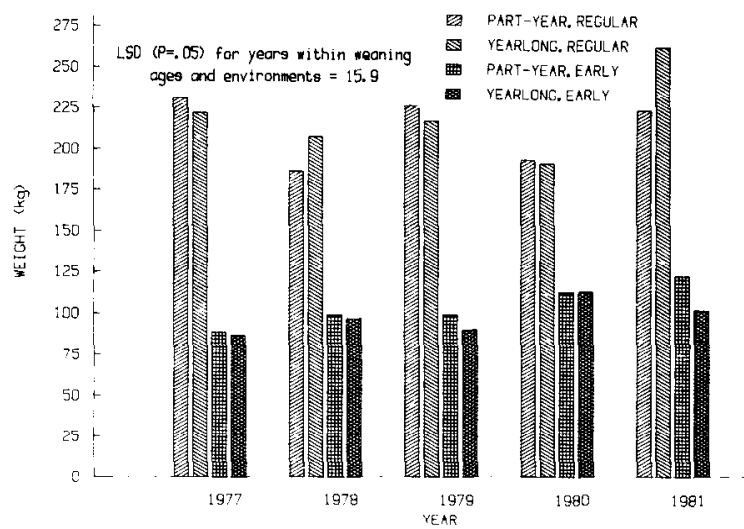

Fig. 2. Adjusted weaning weights during 1977-81 for calves weaned in mid-October and in late May from cow's in part-year confinement and on rangeland yearlong.

(ADG) for 1977-81 of the calves weaned in October from cows in part-year confinement when we assumed a birth weight of $34 \mathrm{~kg}$, was $0.80,0.69,0.84,0.71$, and $0.83 \mathrm{~kg}$, respectively. From cows on range yearlong, mid-October weaning weights were significantly higher $(p<.05)$ in 1981 than the other years and higher in 1977-79 than in 1980 (Fig. 2). The ADG for 1977-81 of the calves weaned in October from cows on range yearlong was $0.81,0.75,0.84,0.71$, and $1.06 \mathrm{~kg}$, respectively. The weight of calves weaned in late May from cows in part-year confinement was significantly greater in 1980 and 1981 than 1977 , and greater in 1981 than 1977-79. The ADG for this group of calves for 1977-81 was $0.70,0.78,0.79,0.92$, and $0.92 \mathrm{~kg}$, respectively. The early weaners from cows kept on range yearlong had a significantly higher weaning weight in 1980 than in 1977 or 1979 (Fig. 2). These calves had an ADG for 1977-81 of $0.70,0.71,0.71,0.83$ and $0.75 \mathrm{~kg}$, respectively.

The production per cow exposed to a bull [(calves weaned $X$ weaning weight)/no. cows] tended to be higher in the part-year confinement group $(134 \mathrm{~kg})$ than in the range group $(110 \mathrm{~kg})$ $[p=.123(\# 1), .110(\# 2)]$. It was also significantly higher when calves were weaned at the regular time in October $[156 \mathrm{~kg}(\# 1), 149 \mathrm{~kg}$ $(\# 2)]$ than in late May [88 $\mathrm{kg}(\# 1), 79 \mathrm{~kg}(\# 2)]$. Production per cow was significantly higher in 1981 than 1977-79 (Table 1).

Combining cow weights for the 2 weaning times resulted in very small differences in cow weights within ages and within years for the cows on the range yearlong compared to those with part-year confinement. Early wcaning resulted in heavicr cow weights, particularly in cows when they weaned their first calf $(414 \mathrm{~kg}$ vs. 380 $\mathrm{kg}$ ). The average cow weights at calf weaning in October for $1977-81$ were: $447,430,497,449$, and $507 \mathrm{~kg}$, respectively.

About $79 \%$ of the cows survived until the end of the experiment. Unavoidable death losses were $7 \%$ and culling accounted for $14 \%$ of the cows not finishing the experiment. No difference in losses was found among treatments. Only data from cows completing the experiment were included in the analyses.
The cows consumed $11.8 \mathrm{~kg}$ alfalfa hay and $0.9 \mathrm{~kg}$ corn grain per head per day while they were confined. At $\$ 77.00 / t$ for alfalfa hay and $\$ 220.00 / t$ for corn, it cost $\$ 1.11 /$ day or $\$ 105.45$ to feed the cows in confinement for 95 days. Additionally, the feed costs for bulls for 65 days was $\$ 4.51 /$ cow, for a total of $\$ 109.96 /$ cow. Cows on the range were given an average $0.45 \mathrm{~kg} /$ day of a high protein feed (cottonseed meal pellets) for 95 days. At $\$ 220.00 / t$, feed costs for cows and bulls would be $\$ 9.93 /$ cow. Therefore, at these prices, the feed costs per cow unit were $\$ 100.03$ greater for cows in part-year confinement than for those on the range yearlong. When calf prices are $\$ 1.54 / \mathrm{kg}$, calves from cows in confinement must weigh an additional $65 \mathrm{~kg}$ to pay for the feed $(\$ 100.03 \div \$ 1.54 / \mathrm{kg}=$ $64.95 \mathrm{~kg}$ or $65 \mathrm{~kg}$ ). Table 2 shows the additional production per cow needed to offset feed costs with varying feed costs and calf prices when the cow is kept in confinement for part of the year. In

Table 2. Additional production per cow required to offset feed costs at varying calf selling prices for cows in confinement as compared to those on range.

\begin{tabular}{lccccc}
\hline \multirow{2}{*}{$\begin{array}{l}\text { Additional' } \\
\text { feed costs }\end{array}$} & \multicolumn{5}{c}{ Calf selling price (dollars/kg) } \\
\cline { 2 - 6 } & 1.30 & 1.60 & 1.90 & 2.20 & 2.50 \\
\hline Dollars & & & \multicolumn{4}{c}{$\mathbf{K g}$} \\
50 & 38 & 31 & 26 & 23 & 20 \\
75 & 58 & 47 & 39 & 34 & 30 \\
100 & 77 & 62 & 53 & 45 & 40 \\
125 & 96 & 78 & 66 & 57 & 50 \\
150 & 115 & 94 & 79 & 68 & 60 \\
\hline
\end{tabular}

IFeed costs for cows and bulls in confinement minus feed costs for cows and bulls on rangeland for that same period.

addition to the feed costs, more labor was required for the cattle in part-year confinement but vehicle costs werc higher for the cattlc on range yearlong. For purposes of this economic analyses, these costs were considered to offset one another. Part-year confinement resulted in production of $65 \mathrm{~kg} /$ cow or more in 1977 for the cows 42 months of age, in 1979 for the cows 66 months old, and in 1981 for the cows 90 months old (Table 1). Thus, the same group of cows on rangeland yearlong were adversely affected by conditions in some years although they were in the same group as other cows on rangeland yearlong and cows in part year confinement while they were on the range.

\section{Discussions and Conclusions}

During this study the major differences were among years instead of cow ages. The years 1978 and 1980 were droughty, resulting in a reduction of forage quantity and quality. This reduction was partially compensated in 1980 by the liberal use of supplemental feed. In 1979 there was a significant reduction in number of calves per cow exposed because of the low conception of cows in the range group in 1978. The weaning weights were also lower in 1978 and 1980 for calves weaned in mid-October. Cow weights at calf weaning were also reduced in 1978 and 1980.

Part-year confinement of cows following calving is a useful tool in droughty periods. As calf prices increase and/or feed costs decrease, part-year confinement of range cows is a more viable option. In this study, conception and weaning rates were higher, and production tended to be higher, from cows in confinement part of the year. Early weaning of calves will also improve conception and weaning rates of cows in dry years. The management of calves weaned early may present a problem to a producer unaccustomed to handling young calves weaned from their dams. The performance of range cows and calves will be improved with nutritional assistance during stress periods in the Southwest.

\section{Literature Cited}

Bellows, R.A., R.E. Short, J.J. Urick, and O.F. Pahnish. 1974. Effects of 
early weaning on postpartum reproduction of the dam and growth of calves born as multiples or singles. J. Anim. Sci. 39:589-600.

Laster, D.B., H.A. Glimp, and K.E. Gregory. 1973. Effects of early weaning on postpartum reproduction of cows. J. Anim. Sci. 36:734-740.

Lusby, K.S., R.P. Wettemann, and E.J. Turman. 1981. Effects of weaning calves from first-calf heifers on calf and heifer performance. J. Anim. Sci. 53:1193-1197.

Marion, P.T., J.K. Riggs, and J.L. Amold. 1971. Calving performance of drylot and pasture cows over an 11-year period, p. 5-7. In: Beef Cattle Research in Texas, 1971. Tex. Agr. Exp. Sta. Consolidated PR 2963-2999.
National Academy of Sciences. 1976. Nutrient requirements of beef cattle. NAS/NRC, Washington, D.C.

Short, R.E., R.A. Bellows, E.L. Moody, and B.E. Howland. 1972. Effects of suckling and mastectomy on bovine postpartum reproduction. $J$. Anim. Sci. 34:70-74.

Thomas, G.W., and R.M. Durham. 1964. Drylot all-concentrate feedingan approach to flexible ranching. J. Range Manage. 17:179-185.

U.S. Department of Agriculture. 1965. Recommended procedures for measurement of traits of economic value in beef cattle. United States Beef Cattle Records Committee Report, USDA M-37.

Wiltbank, J.N., J. Bond, and E.J. Warwick. 1965. Influence of total feed and protein intake on reproductive performance in the beef female through second calving. USDA Tech. Bull. 1314 